\title{
Shaping the Santri's Inclusive Attitudes through Learning in Pesantren: A Case Study of Pesantren Al-Anwar Sarang Rembang Indonesia
}

\author{
Abdul Rohman \\ Universitas Islam Negeri Walisongo Semarang, \\ Jl. Walisongo No.3-5, Tambakaji, Kec. Ngaliyan, \\ Kota Semarang, Jawa Tengah 50185, \\ Indonesia; \\ Corresponding Author

\section{Siti Muhtamiroh} \\ Institut Agama Islam Negeri Salatiga, \\ Jl. Lkr. Sel. Salatiga No.Km. 2, Pulutan, Kec. Sidorejo, \\ Kota Salatiga, Jawa Tengah 50716, \\ Indonesia
}

DOI: https://doi.org/10.36941/jesr-2022-0058

\section{Abstract}

Pesantren (Islamic boarding school), a place for religious learning, has been tarnished because it is considered as a breeding ground for extremism and radicalism. This paper aims to examine the view that pesantren is not an institution for radicalism to be seedbed. However, it is an institution that is open, inclusive, and can accommodate modernity. In line with that idea, three questions could be formulated. First, how is the learning curriculum in pesantren? Second, how is the implementation of learning in pesantren? Third, how is the portrayal of inclusive graduates as the learning impact in pesantren? This study uses qualitative research with curriculum/materials and learning methods in pesantren as the object of the study. The data were collected from sources such as kyai (preacher), ustadz, santri (Islamic boarding school students), graduates, administrators of pesantren who were selected by purposive sampling, with documentation study methods, observations, and interviews. The analysis uses a descriptive method to portray the entire curriculum and learning conditions conducted in pesantren. Then they were analyzed interpretively to see the relationship between the formation of santri's inclusive attitudes. This study shows that the curriculum and learning methods have a significant role in shaping the students' attitudes. A sequential-comprehensive curriculum structure and discursive learning methods will form an inclusive (open and tolerant) student personality. Therefore, other pesantren(s) need to transform towards a discursive curriculum and learning to lead to inclusive students.

Keywords: pesantren, curriculum, instruction, inclusivism, radicalism

\section{Introduction}

Pesantren (Islamic boarding school), a place for religious learning, has been tarnished because it is considered as a breeding ground for extremism and radicalism. The facts show that the perpetrators 
of extremism incidents have the background of being students (santri) in pesantren. The hotel bombings in Kuta and Denpasar Bali in 2002 (Fata, 2014) and JW Marriot in 2003 were executed by pesantren graduates. The same incident also occurred at the Australian embassy in 2004; the actors used to study in pesantren. Meanwhile, in the incident at JW Marriott and Ritz-Carlton Hotels Jakarta in 2009, the perpetrators turned out to be pesantren graduates. Therefore, graduates from pesantren are assumed to be the actors of extremism and radicalism. Mursalin's study shows that pesantren has two potentials for their students to be moderate or immoderate (Mursalin \& Katsir, 2010), even it has a high possibility of the emergence of radicalism (Malik et al., 2017; Susanto, 2007). The incidents carried out by the pesantren people above have placed pesantren in a negative stigma and become the spotlight of the international world. The extremism and radicalism behavior has created an image that pesantren is a breeding ground for violence.

The studies on pesantren tend to discuss three things so far: first, pesantren is seen as an oldfashioned, traditional, and backward educational institution (Mukodi, 2013; Damanhuri et al., 2013; Arifin, 2012). It is often identified with a backward educational institution, a "second class" educational institution that cannot be aligned with other educational institutions in the context of the national education system; second, it is less accommodating to the advance and modernism (Ma'arif, Syamsul; Dardiri, Achmad; Suryo, 2015; Burhanuddin, 2014; Basyit, 2017; Burga et al., 2019). With its traditional characters, pesantren is an educational institution that less responds to modernity issues; and third, it is considered as a place for the growth and development of fundamental and radical religious ideas (Malik et al., 2017; Mursalin \& Katsir, 2010; Susanto, 2007). Due to several extremist actors who turned out to be pesantren graduates, the indication of pesantren being attached to a nest of extremism becomes stronger. Even there have been several studies showing that pesantren is a seedbed for the values of friendliness, openness, tolerance (Amin et al., 2019; Huda, 2018; Ma'arif, 2019; Ma'mun, 2020; Marzuki et al., 2020; Noorhayati, 2017; Nuryatno, 2011; Selvia, 2019; Rohman, 2017). However, pesantren is still stigmatized as a breeding place for extremist, radical groups of Islam followers. This study will evaluate the relationship between the inclusivity of students and the curriculum and the implementation of learning in pesantren. This part seems to be still missing from previous studies.

This paper aims to complement the shortcomings of previous studies regarding negative assessments from society about pesantren, where it is claimed to be seedbed institutions for extremism and radicalism. It wants to show that pesantren is an educational institution with an open, inclusive, tolerant and accommodating character regarding the issue of modernity by focusing on the study of curriculum and learning in pesantren. In line with these discourses, three questions are formulated to answer the problems. First, how is the learning curriculum in pesantren? Second, how is the learning implementation in pesantren? Third, how is the portrayal of inclusive graduates as the impact of learning in pesantren? These questions are the main focus of this paper.

This paper argues that the inclusiveness attitude of santri is influenced by the learning type in pesantren. The learning curriculum and methods as the main parts of the learning in pesantren determine the typology of santri's attitudes. A sequential-comprehensive curriculum and discursive learning methods will influence, direct and shape the attitude of santri who are inclusive, open, tolerant, and democratic. The arrangement of a tiered curriculum in learning has influenced and placed santri in an inclusive, open, and non-rigid way of thinking in responding to different things and also facing changes that occur in a society that is always dynamic.

\section{Literature Review}

\subsection{Learning in Islamic Boarding Schools}

Pesantren is an educational institution with strong roots (indigenous) in the Indonesian Muslim community (Usman, 2013). Historically, pesantren has been the forerunner of education that provides changes by prioritizing the value of local wisdom and character development that is integrated into 
the culture of the community (Irfan \& Hemay, 2020). In other words, pesantren as educational institution is an agent who transfers knowledge and shapes the attitudes, behavior, and character of santri (Islamic boarding school students) (Rokhman et al., 2014). This is reflected in the educational goals of pesantren, which include intellectual, physical, and particularly akhlaq (ethics or moral) education (Anas, 2012). Socially, the existence of pesantren has played an essential role in the public education system, where its education is believed to be the last akhlaq of any educational model (Fauzi et al., 2018). In the education of pesantren, there is no standardized curriculum where almost all pesantren(s) teach a combination of different books. According to Lukens-Bull (Ma'arif, 2018), the pesantren curriculum generally can be divided into four forms, namely religious education, experience and akhlaq education, school and general education, and well as skills and courses.

In its implementation, pesantren or Islamic boarding school is grouped into two types, namely traditional pesantren (salaf), which maintains the traditional teaching system, with teaching materials for classical books, which are often called kitab kuning (classical Arabic manuscript) and modern pesantren (khalaf) which seeks to integrate the classical system and schools into the pesantren fully (Anas, 2012). Therefore, pesantren learning is also divided into two, namely learning in salaf pesantren and khalaf pesantren. Salaf pesantren learning is carried out using four methods, namely (1) bandongan, a teacher-centered learning method where the santri sits around the teacher or Kyai (preacher) who reads the book and the santri listens to each book and take notes if necessary; (2) sorogan, a learning method in which the santri faces the teacher one by one by bringing the books they are studying; (3) memorization, it takes place where the santri memorizes specific texts or sentences from the books they are studying; (4) Mudzakarah, which is conducting scientific meetings in order to discuss religious issues in general (Thohir, 2017; Ma'arif, 2018) Meanwhile, the learning method of khalaf pesantren prioritizes education in the formal school system and emphasizes modern Arabic (Tolib, 2015).

\subsection{Pesantren: Inclusivism versus Exclusivism}

There have been many discussions about pesantren. These discussions are various, ranging from those that place it as an institution that plays a role in carrying out the nation's character; on the one hand, some people place it as an institution that hinders changes, even some others claim it as the seedbed of violence. Historically, pesantren has demonstrated its role in the current changes within society (Dhofier, 1994; Steenbrink, 1974; Ziemek, 1986). The embedding of pesantren on the negative side, particularly under the issues of extremism and radicalism, has occurred since the violent incidents occurred where the perpetrators were pesantren graduates. However, there are few pesantren of this type, which Irfan \& Hemay (2020) categorized as salafy/haraky pesantren. According to Abu Bakar, there are three types of pesantren, namely traditional/salaf pesantren, modern/khalaf pesantren, and salafy/haraky pesantren. The salaf pesantren is characterized by the teaching of classical books known as kitab kuning, and it appears in color and upholds the values of tolerance, moderation, and inclusiveness. Beside applying the traditional pattern, the modern pesantren also teaches modern sciences and even establishes formal schools. Meanwhile, salafy/haraky pesantren is characterized by rough, rigid, exclusive religious ideas, and it is not infrequently displaying the attitudes of extremism and radicalism.

The extreme, exclusive, and radical attitudes that occur in pesantren are caused by several things, namely the figure of Kyai (preacher) as a role model, the curriculum taught in it, and the learning methods implemented in it. On the other hand, the inclusiveness as an attitude and openmindedness, respecting differences of opinion, thought, ethnicity, religion is the attitude that must always be encouraged by the educational institutions, including pesantren which historically has played a role as an institution that instills the noble values into society (Rohman, 2017; Lukens-Bull, 2008). In this context, the curriculum as an essential element in the pesantren learning process needs to be constructed appropriately. 


\subsection{Charisma of Kyai}

Being charismatic is one form of leadership in which his followers believe the charismatic leader personality to be an extraordinary individual, possessing supernatural and superhuman abilities obtained from God The Almighty (Djasadi, Wasino, 2012). Charismatic leadership appears in the leadership within the pesantren led by the Kyai. The charismatic leadership of the Kyai has made pesantren not only an educational institution but also a catalyst (agent of change) (Abdelnour et al., 2017). It is shown by the excellent spirit where the public sees the Kyai's figures as people who are experts in the field of religion, and they are seen to be able to provide solutions in the field of social and religion and be able to contribute to the nation in building the young generation (Masrur, 2017). Therefore, Kyai as the leader of an Islamic educational institution is tasked with designing the design of pesantren, which includes curriculum, rules, evaluation systems, and teaching and learning processes, and as the community leader (Arif \& Muhammad, 2015). This idea later makes pesantren become agencies that have the ability and capacity to encourage the creation of social changes and influence one's actions in life (Recht dan Grynszpan, 2019).

According to Ivancevich (Assilah et al., 2018), charismatic leaders are the leaders who embody a motivational atmosphere based on commitment and emotional identity to their vision, philosophy, and style in their subordinates. The charismatic leadership process of the Kyai is interactive and dynamic in influencing others (Ajan et al., 2018). Kyai is a central figure, sacred and authoritative center because of his charismatic figure and has a positive influence on implementing the educational process in pesantren (Syafiq Humaisi et al., 2019). The charismatic Kyai gains public support because he is seen as having akhlaq stability and quality of faith, which generates a form of magnetic personality for his followers (Safi'i, 2020). Kyai or kyai(s) derive their charisma from religious knowledge, particularly from their Sufism (Kesuma, 2014). In society, charismatic Kyai is believed to have karomah, blessing, efficacious, influence, and the ability to predict (Karim et al., 2017). The leadership of charismatic Kyai in pesantren is caused by the belief of the santri and community that Kyai is an individual appointed as an extension of God's hand in conveying the teachings of the Lord (Rosita, 2018).

\section{Method}

This pesantren becomes the place for this study due to several reasons. First, this pesantren applies a classical system of learning with clear gradations for its students, so the students can study religions in sequence according to the gradation/class. Second, this pesantren implements a curriculum with a clear scope and sequence according to gradations/classes, so that the students can learn religions in stages. This makes learning easier for students, since they can learn the lessons from easy/simple to complex ones. Third, this pesantren has thousands of students with various geographical backgrounds from all over Indonesia, even from other country. This makes students interact with one another so that cultural acculturation will occur which affect their openness (inclusiveness). Fourth, this pesantren can be categorized as an old pesantren with alumni who have been successful to be prominent figures in society with moderate, tolerant, and democratic types of Muslims.

This research took the object of study on curriculum and learning methods in pesantren. These two things were chosen because of their powerful position and roles in forming students' attitudes. These two variables would determine the attitudes of inclusiveness or exclusivity of students. The curriculum materials are related to cognitive aspects, and they will affect an individual's affective aspect in turn. At the same time, the learning method is related more to the affective aspect directly. This research uses a qualitative method, with the primary data in the form of curriculum documents, learning practices, practiced habits, the performance of graduates of Pesantren Al-Anwar Sarang Rembang. The secondary data were in other information such as reference books, printed media sources, electronic media sources related to Pesantren Al-Anwar. The participants in this study were Kyai, ustadz, santri, graduates, administrators of pesantren who were selected using purposive 
sampling. This sampling technique was chosen to ensure that the informants are the right persons and best understands the information needed in this research.

The curriculum data of Pesantren Al-Anwar were collected from the curriculum documents and interviews with Kyai and Ustadz. Meanwhile, the data on the implementation of learning and habituation were collected through interviews with Kyai of pesantren, ustadz who teach in madrasah (Islamic school), santri, alumni. The curriculum data, learning methods, and habituation in pesantren were analyzed using descriptive methods to provide an overview of the curriculum structure, the learning implementation in pesantren. Concerning the curriculum, the aspects collected were the subjects' structure and the books that become references. Then, the description of the curriculum and learning methods were analyzed using interpretive analysis to see how they relate to the inclusiveness of the santri. Does the structure of the curriculum and learning methods implemented in Islamic boarding schools contribute to the inclusive or exclusive attitudes of santri?

\section{Results}

The learning patterns in pesantren will determine the attitudes possessed by santri, namely inclusive or exclusive. Among the pillars of learning that give color to the subject of education are the curriculum and the methods used. The following are the descriptions of three main things: the contents of the curriculum, the learning methods applied in pesantren, and the attitudes of santri as the impact of learning in pesantren.

\subsection{Curriculum Structure and Learning Methods in Pesantren}

All activities carried out at Pesantren Al-Anwar Sarang Rembang are an elaboration of their visions and missions. The visions are formulated to cover all activity programs of pesantren. The formulation of Pesantren Al-Anwar Sarang Rembang's visions: “(a) To create a pesantren that can produce graduates who can master Islamic disciplines and have noble character and care for others. (b) To consolidate the faith and piety as well as develop Islamic knowledge to achieve life happiness in this world and the hereafter based on the Qur'an and Al-Sunnah (Curriculum Documents of Pesantren AlAnwar).

As shown in Table 1, Pesantren Al-Anwar Sarang Rembang consists of a formal curriculum (written curriculum) and a hidden curriculum. The formal curriculum is structured in stages, namely i'dadiyah (preparation) classes, Madrasah Tsanawiyah classes, Madrasah 'Aliyah classes, and post Madrasah classes. The I'dadiyah classes are classes to prepare santri to take part in the learning programs of Madrasah Tsanawiyah classes. Madrasah Tsanawiyah are divided into three levels (marhalah), namely marhalah 1, marhalah 2 and marhalah 3. Madrasah Aliyah are also divided into three marhalah, namely marhalah 1, marhalah 2 and marhalah 3. Post Madrasah programs are classes intended for santri who have completed all previous programs. At the same time, the hidden curriculum is packaged in the form of habituation and learning practices.

"Santri are accustomed to praying five times in congregation, respecting each other and respecting fellow students, living simply, living independently. In addition, there are also learning practices that provide freedom of opinion in discussing the book's contents in the "discussion" forum. In this discussion, santri discusses the contents of the book according to the level by senior santri. Every santri is allowed to express their opinion about the understanding of the book" (interview with Gus Wafi, Pesantren Caregiver).

Based on the researcher's observations, the hidden curriculum is also in the form of "interaction of santri with modern developments, access to outside information, access to newspapers that can be read, television that can be seen, internet that they can access." The caregivers are also figures who are actively involved in the life of the nation and state, for example, KH Taj Yasin 
Maemun Zubair, who is one of the caregivers of Pesantren Al-Anwar who is currently the Deputy Governor of Central Java.

The curriculum that has been shown in Table 1 can be mapped into four major sections. First is the group of Fiqh (Islamic Law), akhlaq (Sufism), and Tawheed subjects. These three lessons are typical lessons taught in pesantren. Fiqh taught in pesantren has levels as shown in Table 1. Taj Yasin stated that "the sequence of fiqh curriculum is based on consideration of coverage and depth of discussion levels." Second, the Arabic language, which includes aspects of grammar, morphology, literature, is taught and studied by santri in stages, as shown in table 1, starting from low to high. This field is studied to provide a linguistic basis for santri to study religious sources of various scientific fields later independently. Third, the Rules of Fiqh and Ushul Fiqh are subjects that provide a philosophical and methodological basis for religious practice. Fourth, the Qur'an and hadith are a group of subjects that are studied at the final stages after they have learned the basics of religion. According to KH Abdul Ghofur, the Kiayi of Pesantren Al-Anwar, he explained that:

\begin{abstract}
"The curriculum is arranged in a sequential and tiered manner. It is carried out to provide convenience to santri in learning. In studying the field of Fiqh (Islamic law), the curriculum is presented from a simple book (kitab safinat al-naja), later increasing to Kitab Matan al-Ghayah, Fath al-Qorib al-Mujib, Fath al-Muin, Minhaj al-Tholibin, then al-Wajiz fi al-figh. The santri will find it easier to learn by this sequence because they will start with a simple discussion. It is different if students learn Fiqh directly using the Minhaj al-tholibin book without studying the previous books of a lower level, they will have difficulties."
\end{abstract}

During the learning process, Pesantren Al-Anwar Sarang Rembang applies three models, namely classical, individual, and discussion. In classical learning, the santri are grouped into classes. The learning is carried out starting from the preparatory classes (marhalah), grades 1-6, and postmadrasah classes. In individual learning, the santri present their ability to master certain books to the kyai/ustadz according to their level. Meanwhile, in the discussion, the santri held discussions about their mastery of a book studied. They even debated the understanding of texts or books associated with cases emerging in society (results of an interview with Ustadz Sukron, one of the senior santri who also teaches at the pesantren). Gus Wafi, one of the caregivers, explained:

\begin{abstract}
"With this discussion, the santri will be trained to respect and interact with other people and other perspectives regarding the issues discussed. Muhadlarah is a kind of discussion method where the santri can exchange their ideas, debate in a discussion about the contents of kitab kuning to deepen their understanding. This method is not only applied to "high-level santri," but also to the santri at the preparation level."
\end{abstract}

Even this kind of interaction with other parties also occurs in everyday life. The santri from various regions in Indonesia mingle with each other, either in the learning process, interaction, or their rooms. Santri are not allowed to live in the rooms where the individuals come from the same area (interview with Ustadz Sukron, one of the senior santri, administrators, and ustadz at the pesantren).

\title{
4.2 Sequential-Comprehensive Curriculum
}

The curriculum content is constructed from the simple to the complex one. For example, Fiqh at the i'dadiyah (preparation) level uses the Safinat al-Naja book. In this book, the discussion is only about Islamic purification, prayer, fasting, and pilgrimage. The discussion is also brief, and it uses simple Arabic. At the Madrasah Tsanawiyah (MTs) level, the material has been improved by using the book of Matan Ghayah wa al-Taqrib (MTs grade 1) and Fath al-Qorib al-Mujib (MTs grade 2 and 3), whose discussions are more complex. At the Madrasah Aliyah level, fiqh material uses the book of Fathul Mu'in (for grades 1 and 2) and Minhaj al-Tholibin (for grades 3). The book of Fath al- 
Mu'in and Minhaj al-Tholibin are books of Fiqh whose discussions are complete, and the discussions are in-depth (results of an interview with Gus Wafi, the caregiver of the pesantren).

Likewise, in aqidah, the curriculum starts from the most straightforward book in content and discussion, namely Aqidat al-Awam, followed by al-Khoridah al-Bahiyah, Bad'u al-Amaly, Jawharat alTawhid, Kifayat al-Awam, Ummu al-Barahin, to the Kitab al-Hushun al-Hamidiyah. This order is carried out with consideration so that the santri learn in sequence for their understanding is getting better. The curriculum in pesantren covers all religious and non-religious materials. Religious materials cover the fields of Tawhid, Fiqh, Al-Quran, Hadith, History, Akhlaq, and various auxiliary sciences, both related to language and others, such as Grammar, Morphology, Science of al-Tafsir, Science of al-Hadith, Ushul al-Fiqh, Qowaid al-Fiqh.

\begin{abstract}
"Pesantren Al-Anwar Sarang Rembang, which is a salaf model pesantren, still maintains the teaching of classical books as the core of education. The madrasah system was established only to facilitate the sorogan system used in the old form of recitation institutions without introducing the teaching of general knowledge. The sorogan and bandongan systems are straightforward learning systems, but they have great meaning in learning and improving the ability of the santri. However, for senior santri, for those who continue their education to higher education, STAI Al-Anwar at Pesantren Sarang, they do not only learn about religious knowledge but also general knowledge." (an interview with Ustadz Sukron, one of the Ustadz who teaches at Pesantren Al-Anwar).
\end{abstract}

Table 1: Curriculum of Pesantren Al-Anwar Sarang Rembang

\begin{tabular}{|c|c|c|c|c|c|c|c|c|c|c|c|c|c|c|c|c|c|c|c|c|}
\hline \begin{tabular}{|l} 
Subjects \\
Level
\end{tabular} & Tanthid & Fiqh & Grammar & Monphologr & $\begin{array}{l}\text { Grammatical } \\
\text { Analysis }\end{array}$ & \begin{tabular}{|l|} 
Mophohology \\
Anarsis
\end{tabular} & \begin{tabular}{|l} 
Bahghahah \& \\
'Arud \\
\end{tabular} & Alshha/tasaruf & Tajuid & Dilte & History & $\begin{array}{l}\text { Fanaid } \\
\text { Science }\end{array}$ & $\begin{array}{l}\text { Ualun } \\
\text { Fiqh }\end{array}$ & $\begin{array}{l}\text { Fich } \\
\text { Punciple }\end{array}$ & Hadits & $\begin{array}{l}\text { Hadtes } \\
\text { Science }\end{array}$ & Tafir & Logic & \begin{tabular}{|l|} 
Tafirir \\
Science
\end{tabular} & $\begin{array}{l}\text { Falk } \\
\text { Science }\end{array}$ \\
\hline I'dadiyah & \begin{tabular}{|l} 
Acqidat al \\
Awram
\end{tabular} & $\begin{array}{l}\text { Safunah } \\
\text { an-Napap }\end{array}$ & $\begin{array}{l}\text { Att-Timar } \\
\text { al-fanigyah }\end{array}$ & $\begin{array}{l}\text { al-Amtuhh at } \\
\text { Tashnifygal (I) }\end{array}$ & $\begin{array}{l}\text { al-Frob I al- } \\
\text { Alfazh al. } \\
\text { Mluththosidah }\end{array}$ & $\begin{array}{l}\text { al-Thal I al- } \\
\text { Amtalihh }\end{array}$ & - & 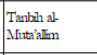 & $\begin{array}{l}\text { Hidaryah } \\
\text { ash- } \\
\text { Shibran }\end{array}$ & Ineyga & - & - & - & - & - & - & - & - & - & - \\
\hline $\begin{array}{l}\text { Marhalah } \\
1\end{array}$ & $\begin{array}{l}\text { al-Khooidah } \\
\text { al-Balingyah }\end{array}$ & $\begin{array}{l}\text { Matatn at } \\
\text { Ghoyah }\end{array}$ & \begin{tabular}{|l|} 
At- \\
Upumizah
\end{tabular} & $\begin{array}{l}\text { alA-Amtulahh at- } \\
\text { Tasnifyghah (II) }\end{array}$ & al-Kafrandy & $\begin{array}{l}\text { Qavaidid at- } \\
\text { Thal }\end{array}$ & - & $\begin{array}{l}\text { al-Washoga at- } \\
\text { aba' I alabolna' }\end{array}$ & $\begin{array}{l}\text { Hidayah } \\
\text { al } \\
\text { Mustafid }\end{array}$ & Insya & - & - & - & - & - & - & - & - & - & - \\
\hline $\begin{array}{l}\text { Marhalah } \\
2\end{array}$ & \begin{tabular}{|l} 
Badu al \\
Amali
\end{tabular} & $\begin{array}{l}\text { Fath at } \\
\text { Qoanb }\end{array}$ & al'Amnitily & al-Kayhany & $\begin{array}{l}\text { at-Qawalid } \\
\text { Ash } \\
\text { Shoofingah }\end{array}$ & $\begin{array}{l}\text { Qouvidid at } \\
\text { Imb' }\end{array}$ & - & $\begin{array}{l}\text { Talim at } \\
\text { Mlutalim }\end{array}$ & $\begin{array}{l}\text { al- } \\
\text { Jazanityah }\end{array}$ & Insya & \begin{tabular}{|l} 
Krnlashoh \\
Nur at \\
Yacina \\
\end{tabular} & - & - & - & - & - & - & - & - & - \\
\hline $\begin{array}{l}\text { Marhabah } \\
3\end{array}$ & \begin{tabular}{|l|} 
Jarutharoh at \\
Tauthid
\end{tabular} & $\begin{array}{l}\text { Fath a at- } \\
\text { Qonolb } \\
\text { III) }\end{array}$ & $\begin{array}{l}\text { Ibma Adq } \\
\text { (I) }\end{array}$ & \begin{tabular}{|l} 
Narhm at- \\
Tashonif
\end{tabular} & \begin{tabular}{|l} 
Kifaysah at- \\
Ashlablb
\end{tabular} & & - & $\begin{array}{l}\text { Mrihaj as- } \\
\text { Sa'acalh }\end{array}$ & - & Insya & $\begin{array}{l}\text { Klnubahoh } \\
\text { Nur at } \\
\text { Yacin (II) }\end{array}$ & \begin{tabular}{|l|} 
Hiffyh \\
at- \\
Turats
\end{tabular} & $\begin{array}{l}\text { al. } \\
\text { Waroqot }\end{array}$ & 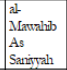 & $\begin{array}{l}\text { Mulkhtashor } \\
\text { Alij Jamroh }\end{array}$ & - & - & - & - & - \\
\hline $\begin{array}{l}\text { Marhalah } \\
4\end{array}$ & \begin{tabular}{|l} 
Kifarah al- \\
Amram
\end{tabular} & $\begin{array}{l}\text { Fatitul } \\
\text { Musin (I) }\end{array}$ & $\begin{array}{l}\text { Inxm Aqp } \\
\text { (I) }\end{array}$ & & - & & - & - & - & . & $\begin{array}{l}\text { Tankls al } \\
\text { Hawadits }\end{array}$ & - & \begin{tabular}{|l|}
$\begin{array}{l}\text { Latho if } \\
\text { al-Istyarot }\end{array}$ \\
\end{tabular} & \begin{tabular}{|l|} 
al \\
Marwalyb \\
As \\
Sanigralh \\
\end{tabular} & $\begin{array}{l}\text { Butigh al- } \\
\text { Marom (I) }\end{array}$ & $\begin{array}{l}\text { aL-Qavalid } \\
\text { al-Asasyyah }\end{array}$ & - & - & - & - \\
\hline \begin{tabular}{|l|} 
Marhalah \\
5
\end{tabular} & $\begin{array}{l}\text { Umm al- } \\
\text { Barchin }\end{array}$ & $\begin{array}{l}\text { Fathl at } \\
\text { Mrian (II) }\end{array}$ & $\begin{array}{l}\text { Syuctzo } \\
\text { actz. } \\
\text { Dzahab }\end{array}$ & & - & & \begin{tabular}{|l} 
ab-jarwhar al- \\
Maknum \& al- \\
Mrikhtaghor \\
asy-Syafy
\end{tabular} & Mnlnaj al-Abidan & & & $\begin{array}{l}\text { Figh as- } \\
\text { Siroh }\end{array}$ & - & $\begin{array}{l}\text { Lublo at } \\
\text { Uslud }\end{array}$ & $\begin{array}{l}\text { allAssbah } \\
\text { wa an- } \\
\text { Nazha ir }\end{array}$ & $\begin{array}{l}\text { Bubrght al- } \\
\text { Marom (II) }\end{array}$ & $\begin{array}{l}\text { at-Taqnirat } \\
\text { As Sanigyah }\end{array}$ & $\begin{array}{l}\text { Tafirir al } \\
\text { Jahharn } \\
\text { (II) }\end{array}$ & \begin{tabular}{|l|} 
Sullam \\
al. \\
Mulatury
\end{tabular} & $\begin{array}{l}\text { Naly at- } \\
\text { Taryir }\end{array}$ & \\
\hline $\begin{array}{l}\text { Marhalah } \\
6\end{array}$ & $\begin{array}{l}\text { al-Hushun } \\
\text { at- } \\
\text { Hamididyah }\end{array}$ & $\begin{array}{l}\text { Minhay } \\
\text { at- } \\
\text { Thollibin }\end{array}$ & $\begin{array}{l}\text { Mrughni al } \\
\text { Lalabs }\end{array}$ & & - & & - & $\begin{array}{l}\text { Mrinhay at- } \\
\text { Aabidin }\end{array}$ & - & Distat & $\mid \begin{array}{l}\text { Figh as- } \\
\text { Siroh }\end{array}$ & - & $\begin{array}{l}\text { Ghogah } \\
\text { al- } \\
\text { Wushul }\end{array}$ & $\begin{array}{l}\text { alAsigbah } \\
\text { wa an- } \\
\text { Nazha ir }\end{array}$ & \begin{tabular}{|l} 
At-Taind at \\
Shooch
\end{tabular} & $\begin{array}{l}\text { al-1arathal } \\
\text { alLattif }\end{array}$ & $\begin{array}{l}\text { Tafsir al } \\
\text { Jahlaryn } \\
\text { (III) }\end{array}$ & $\begin{array}{l}\text { Sulam al } \\
\text { Minkarty }\end{array}$ & 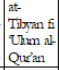 & $\begin{array}{l}\text { Fath as } \\
\text { Rouf al } \\
\text { Manan }\end{array}$ \\
\hline $\begin{array}{l}\text { Post } \\
\text { Macrasah }\end{array}$ & $\begin{array}{l}\text { Nubra al } \\
\text { Yacingyah }\end{array}$ & $\begin{array}{l}\text { Altwajzz } \\
\text { fial-Figh }\end{array}$ & & & & & - & & - & - & \begin{tabular}{|l} 
Alseainh al \\
Nabartigah
\end{tabular} & - & \begin{tabular}{|l|} 
Attar al \\
Ishithlaf
\end{tabular} & $\begin{array}{l}\text { Alqumnid } \\
\text { al-Fiquaryah }\end{array}$ & & 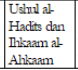 & \begin{tabular}{|l|} 
Tafsir \\
Ayat al. \\
Ahksum
\end{tabular} & - & $\begin{array}{l}\text { Traz al- } \\
\text { Quran }\end{array}$ & - \\
\hline
\end{tabular}

Santri, who studied at Pesantren Al-Anwar Sarang Rembang, learned the materials that are not only from one source and one author, but they use various sources and authors. For example: When studying Tawheed, the santri will study the book of 'Aqidatul Awam, al-Khoridah al-Bahiyyah, Bad'u al-Amali, Jawharoh at-Tawhid, Kifayah al-'Awam, Umm al-Barohin, al-Hushun al-Hamidiyyah, Kubra al-Yaqiniyah. These books discuss Tawheed, but the discussion is graded from the simplest to the complex in terms of the Arabic language's content, scope, and structure. Likewise, when the santri learn about Arabic Grammar, they will study the books of Ats-Tsimar al-Janiyyah, al-Ujrumiyyah, al'Amrithy, Ibnu 'Aqil, Syudzu adz-Dzahab, Mughni al-Labib. These books are about grammar with content and complexity that is graded sequentially from the simplest to the complex.

"In pondok pesantren, religious principles are taught by adhering to Sunni theology. In this context, pesantren have the basic concept that in the case of faith, they follow the opinions of Imam Abu Hasan al-Asyari and Imam Abu Hasan al-Maturidi. In contrast, in terms of fiqh, they follow the ideas of four Islamic schools of thought, namely the Hanafi, Maliki, Shafi'i, and Hambali schools of thought. While in Sufism, they followed Imam Junaid al Baghdadi and Imam Abu Hamid al Ghazali. The repetition of 
subject matter in the pesantren is not only a matter of cognitive pursuit. However, the santri are always required to understand, master, and practice the teachings developed in the pesantren. Therefore, after graduating from the pesantren, they can become flexible people who are not trapped in a textualnormative mindset." (Interview with Gus Wafi and Taj Yasin, Caregivers of Pesantren Al-Anwar Islamic)

The santri who study at Pesantren Al-Anwar Sarang Rembang are classified into eight levels: preparatory, marhalah 1-6, and post-madrasah. These eight levels are a unified program and continuity in all areas of study. During the learning process, the santri are taught classically and individually according to the field of study. They also learn by discussion in class with Kyai/Ustadz in their respective classes to explore and master the fields of study. As Wafi bin Maemun Zubair (one of the caregivers of Pesantren Al-Anwar Sarang Rembang) explained, "to be declared graduated, a santri must master the books used as guidelines in the pesantren. Even, they must memorize in full or in part of the contents of certain books. It is the proof that pesantren teaches a high intellectual culture."

\title{
4.3 Profile of Inclusive Santri as Impact of Learning in Pesantren
}

The graduates' inclusiveness of Pesantren Al-Anwar Sarang Rembang can be seen from their way of thinking. For example, Ahmad Muthohar, one of the alumni, has an open attitude towards various thoughts, ideologies, understandings, and sects. His concern for various ideas, both in the eastern and western parts of the world, indicates an inclusivity. As a lecturer in Islamic Studies and Islamic Philosophy at the Perguruan Tinggi Agama Islam (PTAI - Islamic Higher Education), he views various modes of thought, both mainstream and non-mainstream. In this context, he stated his views on "postmodernism" that:

\begin{abstract}
In the current era, postmodernism is a necessity. Postmodernism which is characterized by three things, namely deconstruction, pluralistic, relativistic, is a thought that can be adopted and adapted by a person in their national and religious life. Deconstruction is an attempt to re-question established ideas, ideologies, theories, and concepts. Nothing is always established in this world. In contrast, pluralistic is a thought which views that there is no single truth reality in various human thoughts. Realities are diverse, and cultures are diverse, religions are diverse, races are diverse, languages are diverse, everything is diverse, pluralistic. Therefore, this is related to the third characteristic, relativistic, that everything is relative and nothing is always absolute. Therefore tolerance, openness, respect for others are just so that religious and state life can run well. Intolerance, extremism, exclusivism are dangerous thoughts, attitudes and behaviors" (Interview with Ahmad Muthohar).
\end{abstract}

Based on the excerpt of the interview above, it can be seen that the graduates of Pesantren Rembang have an inclusive mind.

The inclusiveness of graduates from Pesantren Al-Anwar Sarang Rembang as an impact of the pesantren education process is also reflected in the religious understanding in one of the abiturens, KH Ahmad Baha'uddin Nur Salim. Kyai, who is often called Gus Baha' is one of the Nahdlatul Ulama clerics who currently sits as Rais Syuriah in the Nahdlatul Ulama Executive Board (PBNU). Gus Baha is the son of an al-Quran cleric, KH Nur Salim al-Hafidz from Narukan Kragan Rembang. He is now the caretaker and Kiayi of the Pesantren Tahfidz al-Qur'an LP 3 IA Narukan Kragan Rembang. He is an open cleric and able to get along with all circles. The recitations and studies held also have received positive responses from all segments and various directions. His studies could also be accessed through social media such as Youtube, Facebook, and Instagram. Among the quotes about Gus Baha:

"Ahmad Bahauddin Nur Salim, better known as Gus Baha, is one of the figures of Nahdlatul Ulama whose talks are always eagerly awaited, especially by millennials. This pupil of KH Maemun Zubair or Mbah Moen always politely delivers his studies with easy-to-understand explanations. This scholar from Rembang, Central Java, is also famous for his simplicity and humility. When appearing on the Shihab \& Shihab talk show uploaded on Najwa Shihab's YouTube channel, he admitted that he did not have a 
smartphone or social media. It is quite surprising, considering that content about Gus Baha can always attract the attention of netizens to go viral on social media. "So the commitment of my heart is only to introduce that God's teachings are beautiful, God's teachings are the solution. I never thought that would be viral or become famous. Even now, I don't know if it is famous, I don't have WA, I don't want to hear it," he said. (Source:https://kumparan.com/berita-hari-ini/profil-gus-baha -simple-scholarfavorite-youth-1vEjH 7 FRoY)

Based on the narrative of this paragraph, it can be seen that the alumni of Pesantren Al-Anwar Rembang have shown an open and inclusive behavior that can interact with outside parties well.

The inclusiveness of the graduates can also be seen from the figure of Mizan Sya'roni, who currently works at the Ministry of Religious Affairs of Indonesia. Before studying at Pesantren AlAnwar Sarang Rembang, Mizan had studied at the Mathali'ul Falah Islamic College in Kajen Margoyoso Pati (an Islamic educational institution led by KH. Sahal Mahfudz), then continued his education to IAIN Walisongo (now UIN Walisongo). After that, he continued to study Islam in the Institute of Islamic Studies at McGill University Canada to get his master (MA) program in Islamic Studies. When asked about why studying Islam in the West, he explained:

\begin{abstract}
"As a Muslim, learning can be done anytime, anywhere, in any situation, including studying in the West. Learning about Islam does not always have to be in Middle Eastern countries, such as Egypt, Saudi Arabia. Learning Islam can also be done in the West, such as in America, Europe, Australia, because Western countries have a good approach or methodology to studying Islam. Armed with the normative sciences from pesantren, it would be better with methodological enrichment in Western countries" (an interview with Mizan Sya'roni).
\end{abstract}

Based on the respondents' narratives, it can be stated that the graduates of Pesantren Al-Anwar Sarang Rembang have indicated the existence of inclusive, tolerant, and open thoughts, attitudes, and behaviors.

\title{
5. Discussion
}

The learning carried out at Pesantren Al-Anwar Sarang Rembang begins with the learning of the essential dimensions of Islam, namely Fiqh, akhlaq, Sufism, Islamic history, and other linguistic sciences in the lower classes, then proceeds to the fields of al-Quran, al-Hadith and enriched with philosophical and methodological sciences such as Ushul al-Fiqh, Qawaid al-Fiqhiyah, Ilmu al-Hadith, Ilmu Al-Quran in high classes. Learning with this curriculum structure tends to place the santri with diverse horizons of understanding about the religion they believe. This kind of curriculum leads the santri to a coherent and deep understanding. It will have implications for having an open, inclusive, and tolerant attitude towards various kinds of differences (Fata, 2014; Kusmanto et al., 2015; Ma'arif, 2015; Ni'am, 2015). It is different from those who learn about Islam directly from the verses of the Qur'an and the matan of al-Hadith, without being preceded by other sciences; this will tend to lead to a rigid and exclusive understanding of Islam (Thohir, 2017). Moreover, if their learning is not assisted by qualified teachers and only learn through social media, they will tend to have a shallow and less comprehensive understanding of religion. It will potentially lead to extreme religious understanding in turn (Rusli, 2014; Rohman, 2016; Rohman, 2017).

The graduates from Pesantren Al-Anwar who tend to have open and inclusive thoughts, attitudes, and associations are the outcomes of the curriculum construction. It has been arranged sequentially, both in scope and sequence, starting with an understanding of the basics of Islam, such as fiqh, akhlaq, Sufism, then proceeding to other aspects. It also reinforces the learning methods application where the santri can interact with other parties openly, learning methods that provide a broad space of reasoning for santri (Gazali \& Malik, 2009; Lukens-Bull, 2008). Therefore, the rise of extremism, radicalism, intolerance, violence that has occurred in recent times, among others, is caused by the learning process they experience is different from the pattern practiced at Pesantren 
Al-Anwar or other institutions with the same type (Fata, 2014; Kusmanto et al., 2015; Ma'arif, 2015; Ni'am, 2015). Studies conducted by several experts explained that the learning in doctrinal pesantren would result in a rigid and literalist understanding of the Qur'an and al-Hadith texts. It will lead to a tendency towards a rigid religious attitude of the santri (Irfan \& Hemay, 2020; Malik, 2017; Mudzakkir, 2017). Furthermore, why does Pesantren Al-Mukmin Ngruki Solo tend to produce relatively complex religious views? It is also because of the textualist learning model factor (TM, 2005; Yumitro et al., 2020).

The vital point drawn from the research findings above is that the sequence of material (both scope and sequence) learned by the santri in learning is an essential factor because it will affect their readiness to learn. The comprehensiveness and depth of the santri on the material learned will affect their attitude of inclusive or exclusive (Rohman, 2016; Rohman, 2017). The curriculum has an essential role in shaping the attitudes of the santri. Therefore, the curriculum arrangement is an aspect that must receive attention. In addition, the use of learning methods is also a second point that needs to be underlined. The attitude of santri will be significantly influenced by the methods practiced during the learning (Ardiansyah, 2018; Lukens-Bull, 2008; Ma'arif, 2019; Syukur, 2019).

This research is different from the previous researches, for example, the study conducted by Damanhuri et al. (2013) which places pesantren as an old-fashioned, traditional, and backward educational institution. A study conducted by Burga et al. (2019) also shows that pesantren is less accommodating to progress and modernity. It is as well as the other studies that stated that pesantren is considered as a place for growth and development of fundamental and radical religious ideas (Malik et al., 2017; Mursalin \& Katsir, 2010; Susanto, 2007). This study found that pesantren which has often been claimed to be an old-fashioned, backward, anti-change, and fundamental institution, actually shows a different side. It is an institution that is open, tolerant, and accommodating to progress and modernity. It can be seen from the structure of the curriculum and the learning process practiced.

Based on the results of this study, the curriculum and methods of learning have a significant role in shaping the attitudes of santri. A sequential-comprehensive curriculum structure and learning methods that provide space for santri to interact with other parties and provide space for expression and reason will form students' open, inclusive, tolerant, and democratic personalities. On the other hand, a closed, doctrinal curriculum plus an expository learning method will tend to form the attitudes of santri who are exclusive, rigid, and less tolerant. Therefore, it is a need for pesantren to transform their curriculum and learning type towards a discursive ones. It can be done by constructing a comprehensive-sequential curriculum and applying discursive learning methods to form and ensure the santri's inclusive and tolerant personality.

\section{Conclusion}

It turns out that the image of pesantren in society that is a hotbed of extremism and radicalism is not proven true. This study has shown the opposite thing that pesantren is an Islamic educational institution that becomes the center of excellence in cultivating the values of inclusiveness and tolerance in the santri. Pesantren has succeeded in establishing itself as an inclusive Islamic educational institution. The curriculum structure indicates it, and learning methods are applied. The curriculum structure is designed starting from the basic Islamic materials (fiqh, aqidah, akhlaq, Islamic history) in the lower classes. It is continued with the interpretation material of the alQur'an and al-Hadith in the high classes. It is enriched with other materials philosophically and methodologically. It turns out to lead the santri to be open and inclusive individuals. Meanwhile, the learning has applied a discursive method that provides space to maximize the function of logical and systematic reasoning. These two things lead the graduates to become santri who are inclusive and not exclusive.

This sequential-comprehensive curriculum construction and discursive learning method will be helpful for Islamic educational institutions in general, including other pesantren, organize a 
curriculum that pays attention to scope and sequence. If this is not considered carefully, there will be potential for extremism to grow. This study is limited to one pesantren, so the description is also specific to that location, even though it is possible to provide an overview of other locations with similar characteristics. Therefore, further discources are needed to enlarge and broaden diverse site of studies to get a more comprehensive picture of pesantren.

\section{References}

Abdelnour, S., Hasselbladh, H., \& Kallinikos, J. (2017). Agency and Institutions in Organization Studies. Organization Studies, 38(12), 1775-1792. https://doi.org/10.1177/0170840617708007

Ajan, A., Mahruddin, A., \& Mulyana, M. A. (2018). Efektivitas Kepemimpinan Karismatik Kyai dalam Meningkatkan Kinerja Guru. Tadbir Muwahhid, 2(1), 33-45. https://doi.org/10.30997/jtm.v2i1.1143

Amin, M. I., Haryani, T. N., Arifah, N. H., \& Husna, A. M. (2019). Islamic Education in Supporting Deradicalization: A Review of Islamic Education in Pondok Pesantren. Nadwa: Jurnal Pendidikan Islam, 12(2), 259-272. https://doi.org/10.2158o/nw.2018.12.2.2581

Anas, A. I. (2012). Kurikulum dan Metodologi Pembelajaran Pesantren. Cendekia: Jurnal Kependidikan Dan Kemasyarakatan, 10(1), 29-44. https://doi.org/10.21154/cendekia.vioi1.40o

Ardiansyah, M. Z. (2018). Higher-Order Thinking Skills: Strategi Kontra Radikalisme Santri Pesantren. Ibriez: Jurnal Kependidikan Dasar Berbasis Sains, 3(2), 121-132.

Arif, I., \& Muhammad, A. (2015). Kepemimpinan kyai dalam membentuk etos kerja santri. Jurnal Manajemen Dakwah, 1(2), 229-243. https://doi.org/10.14421/jmd.2015.\%25x

Assilah, T. F., Sunaryo, H., \& ABS, M. K. (2018). Kepemimpinan Kharismatik Kyai dan Motivasi Kerja Pengaruhnya terhadap Kinerja Guru (Pondok Pesantren PPAI Darun Najah, Ngijo, Karangploso, Malang). Jurnal Riset Manajemen, 7(2), 108-119.

Basyit, A. (2017). Pembaharuan Model Pesantren: Respon taerhadap Modernitas. Kordinat: Jurnal Komunikasi Antar Perguruan Tinggi Agama Islam, 16(2), 293-324. https://doi.org/10.15408/kordinat.v16i2.6444

Burga, M. A., Arsyad, A., Damopolii, M., \& Marjuni, A. (2019). Akomodasi Pesantren Terhadap Kebijakan Pendidikan Nasional. At-Tarbawi: Jurnal Kajian Kependidikan Islam, 4(1), 41-62. https://doi.org/10.22515/attarbawi.v4i1.156o

Burhanuddin, H. (2014). Post-Tradisionalisme Pesantren: Mengukuhkan Tradisi Pesantren sebagai Basis Transformasi di Era Modern. Al Murabbi, o1(o1), 16-32.

Damanhuri, A., Mujahidin, E., \& Hafidhuddin, D. (2013). Inovasi Pengelolaan Pesantren dalam Menghadapi Persaingan di Era Globalisasi. Ta'dibuna: Jurnal Pendidikan Islam, 2(1), 17-38. https://doi.org/10.32832/tadibuna.v2i1.547

Dhofier, Z. (1994). Tradisi Pesantren: Studi tentang Pandangan Hidup Kiai. LP3ES.

Djasadi, Wasino, T. S. (2012). Faktor-Faktor Yang Mempengaruhi Keberhasilan Kyai Kharismatik Dalam Memimpin Pondok Pesantren. Jurnal of Educational and Evaluation, 1(2), 146-151.

Fata, B. S. (2015). Arah Baru Pesantren di Indonesia: Fundamentalisme, Modernisme dan Moderatisme. Esensia: Jurnal Ilmu-Ilmu Ushuluddin, 15(1), 17-39. https://doi.org/10.14421/esensia.v15i1.762

Fauzi, A., Hefniy, H., Baharun, H., Mundiri, A., Manshur, U., \& Musolli, M. (2018). E-Learning in Pesantren: Learning Transformation based on the Value of Pesantren. IOP Conf. Series: Journal of Physics: Conf. Series 1114, 1-6. https://doi.org/10.1088/1742-6596/1114/1/012062

Gazali, H., \& Malik, A. (2009). Pesantren and The Freedom of Thinking: Study of Ma'had Âly Pesantren. AlJami'ah: Journal of Islamic Studies, 47(2), 296-316. https://doi.org/https://doi.org/10.14421/ajis.2009.472.295316

Huda, M. (2018). Eksistensi Pesantren dan Deradikalisasi Pendidikan Islam di Indonesia (Menyemai Spirit Toleransi dan Pendidikan Islam Multikultural). FOKUS Jurnal Kajian Keislaman Dan Kemasyarakatan, 3(1), 85-109. https://doi.org/10.29240/jf.v3i1.458

Irfan, A., \& Hemay, I. (2020). Pesantren Resilience: The Path to Prevent Radicalism and Violent Extremism. Studia Islamika, 27(2), 397-404. https://doi.org/10.36712/sdi.v27i2.16766

Karim, A., Mardhotillah, N. F., \& Rochmah, E. (2017). Dampak Kharisma Kyai Terhadap Miliu Kesalehan Sosial. Seminar Nasional Hasil Penelitian Universitas Kanjuruhan Malang, 5(1), 277-282.

Kesuma, G. C. (2014). Pesantren dan Kepemimpinan Kyai. Terampil : Jurnal Pendidikan Dan Pembelajaran Dasar, 1(1), 99-117. https://doi.org/10.24042/terampil.vii1.1308

Kusmanto, T. Y., Fauzi, M., \& Jamil, M. M. (2015). Dialektika Radikalisme dan Anti Radikalisme di Pesantren. Walisongo: Jurnal Penelitian Sosial Keagamaan, 23(1). https://doi.org/10.2158o/ws.2015.23.1.221 
Lukens-Bull, R. (2008). The Traditions of Pluralism, Accommodation, and Anti-Radicalism in the Pesantren Community. Journal of Indonesian Islam, 2(1), 1-15. https://doi.org/10.15642/JIIS.2008.2.1.1-15

Ma'arif, S. (2015). The Revitalization of Pesantren : Philosophical Thinking to Direction Universalization of Islamic Values. Global Research Journal of Education, 3(5), 314-320.

Ma'arif, S. (2018). Education as a Foundation of Humanity: Learning from the Pedagogy of Pesantren in Indonesia. Journal of Social Studies Education Research, 9(2), 104-123. https://doi.org/10.17499/jsser.58854

Ma'arif, S. (2019). Reinventing Pesantren's Moderation Culture to Build a Democratic Society in the Post-Reform Republic of Indonesia. Pertanika Journal of Social Sciences and Humanities, 27(3), 1739-1751.

Ma'arif, S., Dardiri, A., \& Suryo, D. (2015). Inklusivitas Pesantren Tebuireng: Menatap Globalisasi dengan Wajah Tradisionalisme. Jurnal Pembangunan Pendidikan: Fondasi Dan Aplikasi, 3(1), 81-94. https://doi.org/10.21831/jppfa.v3i1.7814

Ma'mun, M. (2020). Menangkal Faham Radikal Berbasis Pondok Pesantren Bahasa Arab. El-Faqih: Jurnal Pemikiran Dan Hukum Islam, 6(1), 49-79. https://doi.org/10.29062/faqih.v6i1.102

Malik, A. (2017). Stigmatization of Islamic School: Pesantren, Radicalism and Terrorism in Bima. Ulumuna, 21(1), 173-210. https://doi.org/10.20414/ujis.v21i1.1159

Malik, A., Sudrajat, A., \& Hanum, F. (2017). Kultur Pendidikan Pesantren dan Radikalisme. Jurnal Pembangunan Pendidikan: Fondasi Dan Aplikasi, 4(2), 103-114. https://doi.org/10.21831/jppfa.v4i2.11279

Marzuki, Miftahuddin, \& Murdiono, M. (2020). Multicultural Education in Salaf Pesantren and Prevention of Religious Radicalism in Indonesia. Cakrawala Pendidikan, 39(1), 12-25. https://doi.org/10.21831/cp.v39i1.22900

Masrur, M. (2017). Figur Kyai dan Pendidikan Karakter di Pondok Pesantren. Tarbawiyah: Jurnal Ilmiah Pendidikan, 1(1), 272-282. https://doi.org/10.32332/tarbawiyah.viio1.1022

Mudzakkir, A. (2017). Konservatisme Islam dan Intoleransi Keagamaan di Tasikmalaya. Harmoni, 16(1), 57-74. https://doi.org/10.32488/harmoni.v16i1.56

Mukodi. (2013). Tradisionalisme Pesantren di Tengah Arus Perubahan. Jurnal Penelitian Pendidikan, 5(1), 789-852.

Mursalin, A., \& Katsir, I. (2010). Pola Pendidikan Keagamaan Pesantren dan Radikalisme: Studi Kasus Pesantrenpesantren di Provinsi Jambi. Kontekstualita, 25(2), 255-290.

Ni'am, S. (2015). Pesantren: The Miniature of Moderate Islam in Indonesia. Indonesian Journal of Islam and Muslim Societies, 5(1), 111-134. https://doi.org/10.18326/ijims.v5i1.111-134

Noorhayati, S. M. (2017). Pendidikan Multikultural di Pesantren (Upaya Membendung Radikalisme di Indonesia). Madania: Jurnal Kajian Keislaman, 21(1), 67-78. https://doi.org/10.29300/madania.v2111.212

Nuryatno, M. A. (2011). Islamic Education in a Pluralistic Society. Al-Jami'ah: Journal of Islamic Studies, 49(2), 411431. https://doi.org/10.14421/ajis.2011.492.411-431

Recht, S., \& Grynszpan, O. (2019). The Sense of Social Agency in Gaze Leading. Journal on Multimodal User Interfaces, 12(38), 1-12. https://doi.org/10.1007/s12193-018-0286-y

Rohman, A. (2016). Pluralism Based Religious Education for Deradicalization of Religion. Al-Ulum, 16(2), $289-310$. https://doi.org/10.30603/au.v16i2.36

Rohman, A. (2017). Pesantren as a Basis for Internalization of Pluralistic Values for Preparing a Democratic Citizens in a Diverse Society. Walisongo: Jurnal Penelitian Sosial Keagamaan, 25(2), 419-442. https://doi.org/10.21580/ws.25.2.1324

Rokhman, F., Hum, M., Syaifudin, A., \& Yuliati. (2014). Character Education for Golden Generation 2045 (National Character Building for Indonesian Golden Years). Procedia - Social and Behavioral Sciences, 141, 1161-1165. https://doi.org/10.1016/j.sbspro.2014.05.197

Rosita, N. (2018). Kepemimpinan Kharismatik Kiai di Pondok Pesantren Ali Maksum Krapyak Yogyakarta. Sangkep: Jurnal Kajian Sosial Keagamaan, 1(2), 166-183. https://doi.org/10.20414/sangkep.vii2.620

Rusli, R. (2014). Progressive Salafism in Online Fatwa. Al-Jami'ah: Journal of Islamic Studies, 52(1), $205-229$. https://doi.org/10.14421/ajis.2014.521.205-229

Safi 'i, I. (2020). Model Kepemimpinan Kyai dalam Membentuk Santri Mandiri Di Era 4.o. Al-Mada: Jurnal Agama, Sosial, Dan Budaya, 3(2), 218-240. https://doi.org/10.31538/almada.v3i2.656

Steenbrink, K. A. (1974). Pesantren Madrasah Sekolah: Pendidikan Islam dalam Kurun Modern. LP3ES.

Sunarso, S. (2019). Islamic Boarding Schools in Indonesia: Caring for Nationalism and Preventing Radicalism. Jurnal Penelitian, 16(1), 53-63. https://doi.org/10.28918/jupe.v16i1.1822

Susanto, E. (2007). Kemungkinan Munculnya Paham Radikal di “Pondok Pesantren.” Tadris: Jurnal Pendidikan Islam, 2(1), 1-19. https://doi.org/10.19105/tjpi.v2i1.205

Syafiq Humaisi, M., Thoyib, M., Arifin, I., Imron, A., \& Sonhadji, A. (2019). Pesantren Education and Charismatic Leadership: a Qualitative Analysis Study on Quality Improvement of Islamic Education in Pondok Pesantren Nurul Jadid Paiton Probolinggo. Universal Journal of Educational Research, 7(7), $1509-1516$. https://doi.org/10.13189/ujer.2019.070704 
Syukur, T. A. (2019). Teaching Methods in Pesantren to Tackle Religious Radicalism. Jurnal Pendidikan Islam, 5(2), 189-20o. https://doi.org/10.15575/jpi.v5i2.6178

Thohir, K. (2017). Kurikulum dan Sistem Pembelajaran Pondok Pesantren Salafi di Kecamatan Kresek Kabupaten Tangerang Provinsi Banten. Jurnal Analytica Islamica, 6(1), 11-20.

TM, F. (2017). Pondok Pesantren Islam al-Mukmin Ngruki: Studi tentang Faham Keagamaan Salafi. Edukasi: Jurnal Penelitian Pendidikan Agama Dan Keagamaan, 3(2), 95-118. https://doi.org/10.32729/edukasi.v3i2.214

Tolib, A. (2015). Pendidikan di Pondok Pesantren Modern Terpadu. Risalah: Jurnal Pendidikan Dan Studi Islam, 2(1), 6o-66. https://doi.org/10.31943/jurnal_risalah.v2i1.12

Usman, M. I. (2013). Pesantren Sebagai Lembaga Pendidikan Islam (Sejarah Lahir, Sistem Pendidikan, Dan Perkembangannya Masa Kini). Al-Hikmah: Journal of Religious Studies, 14(1), 101-119.

Warsah, I. (2021). Jihad and Radicalism: Epistemology of Islamic Education at Pesantren al-Furqan in Musi Rawas District. Jurnal Ilmiah Islam Futura, 21(2), 152-169. https://doi.org/10.22373/jiif.v21i2.7683

Yumitro, G., Abdullahi Abdelsalam, E., \& Farhana Mohamad Shukri, S. (2020). Middle East Link of Terrorist Threats from the Perspective of Pesantren in Indonesia: Case Study in the Area of Malang. Humanities and Social Sciences Reviews, 8(3), 508-517. https://doi.org/10.18510/hssr.2020.8355

Ziemek, M. (1986). Pesantren dalam Perubahan Sosial. P3M. 